\title{
KŪNO KULTŪROS MOKYTOJŲ MITYBA IR FIZINIS AKTYVUMAS SVEIKATINGUMO ASPEKTU
}

\author{
Daiva Vizbaraitė, Vida Janina Česnaitienè \\ Lietuvos kūno kultūros akademija, Kaunas, Lietuva
}

Daiva Vizbaraitė. Biomedicinos mokslų daktarè. Lietuvos kūno kultūros akademijos Taikomosios fiziologijos ir sveikatos ugdymo katedros lektorè. Mokslinių tyrimų kryptis — mitybos ir fizinio aktyvumo poveikis sveikatai.

\begin{abstract}
SANTRAUKA
Lietuvos bendrojo lavinimo mokyklos bendrosiose programose ir išsilavinimo standartuose teigiama, kad sèkminga šiuolaikinès kūno kultūros sklaida nę̇manoma be sveikos gyvensenos žiniu. Küno kultūros mokytojo veikla glaudžiai susijusi su sveikatos ugdymu, o asmeninè kompetencija turi didžiuli ugdomaji poveikị. Taigi kyla probleminis klausimas, ar kūno kultüros mokytojai, ugdydami moksleiviu sveikq gyvensena, patys gyvena vadovaudamiesi sveikatingumo kriterijais.

Tyrimo tikslas - ištirti kūno kultūros mokytoju mitybq ir fizinį aktyvumq. Tiriamajq imtí sudarè 320 kūno kultūros mokytoju (184 vyrai ir 136 moterys), atsitiktinai parinktu iš Lietuvos bendrojo lavinimo mokyklu. Tiriamuju amžiaus vidurkis - 42,5 $\pm 21,5$ metu. Anketinés apklausos metodu buvo tirta kūno kultūros mokytoju mityba ir fizinis aktyvumas. Apklausos metu naudota Respublikos mitybos centro ir Pasaulinès Sveikatos Organizacijos 1997-1998 metais atlikto Lietuvos žmoniu gyvensenos ir faktiškos mitybos tyrimo anketa (Kadziauskiené ir kt., 1999). Tyrimo rezultatai išreikšti procentais. Duomenys statistiškai reikšmingi, jei paklaidos tikimybe $p<0,05$. Statistinis ryšys vertintas taikant chi kvadrato kriteriju $\left(\chi^{2}\right)$.

Tyrimas parodè, kad kūno kultūros mokytojai nepakankamai dažnai vartoja šviežiu ir virtu daržoviu. Šviežias daržoves moterys valgo dažniau nei vyrai. Daugiau nei pusès tirtu kūno kultūros mokytoju pagrindinis maisto produktu pasirinkimo kriterijus - skoninès savybès. Kūno kultūros mokytojos dažniau nei vyrai vartoja vitaminus ir maisto papildus. Tirti mokytojai vartoja per daug druskos. Pusè visu tirtu kūno kultūros mokytoju vartoja mineralizuota druskq. 39\% kūno kultüros mokytoju vyru ir 35\% moteru vartoja gérimui netinkamq vandeni. Beveik visi tirti mokytojai maistui gaminti vartoja augalinį alieju, tačiau didžioji dauguma nesilaiko mitybos režimo, užkandžiauja tarp pagrindiniu valgymu. Antsvorį turëjo tik 22\% tirtu kūno kultūros mokytoju vyru ir 7\% moteru.
\end{abstract}

Kūno kultūros mokytoju fizinis aktyvumas didesnis nei kitu suaugusiu Lietuvos gyventoju. 60\% tiriamuju mano, kad ju tiesioginis darbas yra vidutiniškai sunkus. Laisvalaikiu fiziškai aktyvesni tirti kūno kultūros mokytojai vyrai nei moterys. 85\% apklaustu kūno kultūros mokytoju vyru ir 75\% moteru laisvalaikiu mankštinasi.

Raktažodžiai: kūno kultūra, mityba, fizinis aktyvumas.

\section{IVADAS}

$\mathrm{N}$ acionalinès sveikatos stiprinimo plètros veiksmu plane ugdymo institucijose 2003-2006 metų laikotarpio viena iš numatytų krypčių — pedagogų rengimas ir tobulinimas moksleivių sveikatos stiprinimo atžvilgiu. Tarp priemonių, padedančių tobulinti pedagogų kvalifikaciją moksleivių sveikatos stiprinimo klausimais, yra pedagogų sveikatos stiprinimo žinių

ir igūdžių įvertinimas. Kūno kultūros mokytojo veikla glaudžiai susijusi su sveikatos ugdymu, o asmeninė kompetencija turi didžiuli ugdomaji poveiki. Nuo mokytojo požiūrio ị sveikatą daug priklauso, kaip jis pasirengs ir prisidès prie sveikatos ugdymo, kiek demesio ir kam skirs per pamokas, koki požiūri skiepys, kaip skatins mokinius tausoti sveikatą (Weare \& Gray, 1995). Vienokie ar 
kitokie mokytojo veiksmai visada grindžiami vertybėmis, pastarosios atsispindi mokytojo elgesyje, nepaisant to, ar mokytojas savo vertybes isisąmonina, ar ne, ir jie neišvengiamai veikia mokiniu nuostatas bei vertybių pasirinkimą (Lepeškiené, 2000). Moksleiviai dažnai elgiasi taip, kaip elgiasi tas žmogus, kuri jie laiko pavyzdžiu. Todèl labai svarbu, kad pedagogo veikla ir jo paties elgesys sutaptu (Almonaitienè ir kt., 2001). Pozityvesnè ugdytojo sveikatos nuostata lemia ir sveikesnio gyvenimo stiliu, o sveikesnis asmuo suinteresuotas išugdyti ir sveiką ugdytini (Puišienè, Ciegiené, 2005). Daugelyje ekonomiškai išsivysčiusių šaliu vyrauja ịsitikinimas, kad judejimo aktyvumas, derinamas su sveika mityba, padeda išsaugoti sveikatą. Rekomenduojama, kad grūdiniai produktai, bulvès, daržovès ir vaisiai sudarytų daugiau nei pusè visos per para gaunamos energijos (Sveikatos apsaugos ministerijos Respublikinis mitybos centras, 1998). Mityba ir fizinis aktyvumas, nors yra skirtingi gyvensenos veiksniai, tačiau neabejotinai tarpusavyje susiję ne tik kasdienès veiklos, bet ir visuomenès sveikatinimo kontekste (Baranovski, 2004). Taigi kyla probleminis klausimas, ar kūno kultūros mokytojai, ugdydami moksleivių sveiką gyvensena, patys gyvena vadovaudamiesi sveikatingumo kriterijais?

Tyrimo tikslas - ištirti kūno kultūros mokytojų mitybą ir fizini aktyvumą sveikatingumo aspektu. Siekiant šio tikslo buvo užsibrěžti uždaviniai:

1. Ištirti kūno kultūros mokytojų mitybos ypatumus.

2. İvertinti kūno kultūros mokytojų fizini aktyvumą.

\section{TYRIMO METODAI}

Tyrimas vyko 2005-2006 mokslo metais. Buvo tirti 320 kūno kultūros mokytojų (184 vyrai ir 136 moterys), atsitiktinai parinkti iš Lietuvos bendrojo lavinimo mokyklų. Tiriamujų amžiaus vidurkis - 42,5 $\pm 21,5$ metu.

Anketinès apklausos metodu buvo tirta kūno kultūros mokytojų mityba ir fizinis aktyvumas. Tuo tikslu naudotasi Respublikos mitybos centro ir Pasaulinès Sveikatos Organizacijos 1997-1998 metais atlikto Lietuvos žmoniu gyvensenos ir faktiškos mitybos tyrimo anketa (Kadziauskiene ir kt., 1999). Norint nustatyti, ar tarp kūno kultūros mokytoju yra turinčiu antsvorị, nutukusių, buvo apskaičiuotas kūno masės indeksas (KMI) pagal formulę: $\mathrm{KMI}=$ kūno mase $(\mathrm{kg}) /$ ūgis $\left(\mathrm{m}^{2}\right)(\mathrm{La}-$ šienė ir Lašas, 1998). Gauti anketinės apklausos rezultatai buvo vertinami skirstant respondentus pagal lyti.

Tyrimo duomenims apdoroti naudotas statistinis paketas SPSS 10.0 for Windows, apskaičiuotas aritmetinis vidurkis, rezultatai išreikšti procentais. Duomenys statistiškai reikšmingi, jei paklaidos tikimybė $\mathrm{p}<0,05$. Statistinis ryšys vertintas taikant chi kvadrato kriteriju $\left(\chi^{2}\right)$.

\section{REZULTATAI}

Iš maisto produktų pasirinkimo kriterijų galima spręsti apie mitybos svarbą asmens sveikatai. Pagal skonines savybes maisto produktus renkasi $65 \%$ vyru ir $61 \%$ moterų. Kitas svarbus maisto pasirinkimo kriterijus moterims yra ligu profilaktika (42\%), vyrams - šeimos nariu ittaka (28\%). Pagal kainą maisto produktus renkasi $20 \%$ vyrų ir

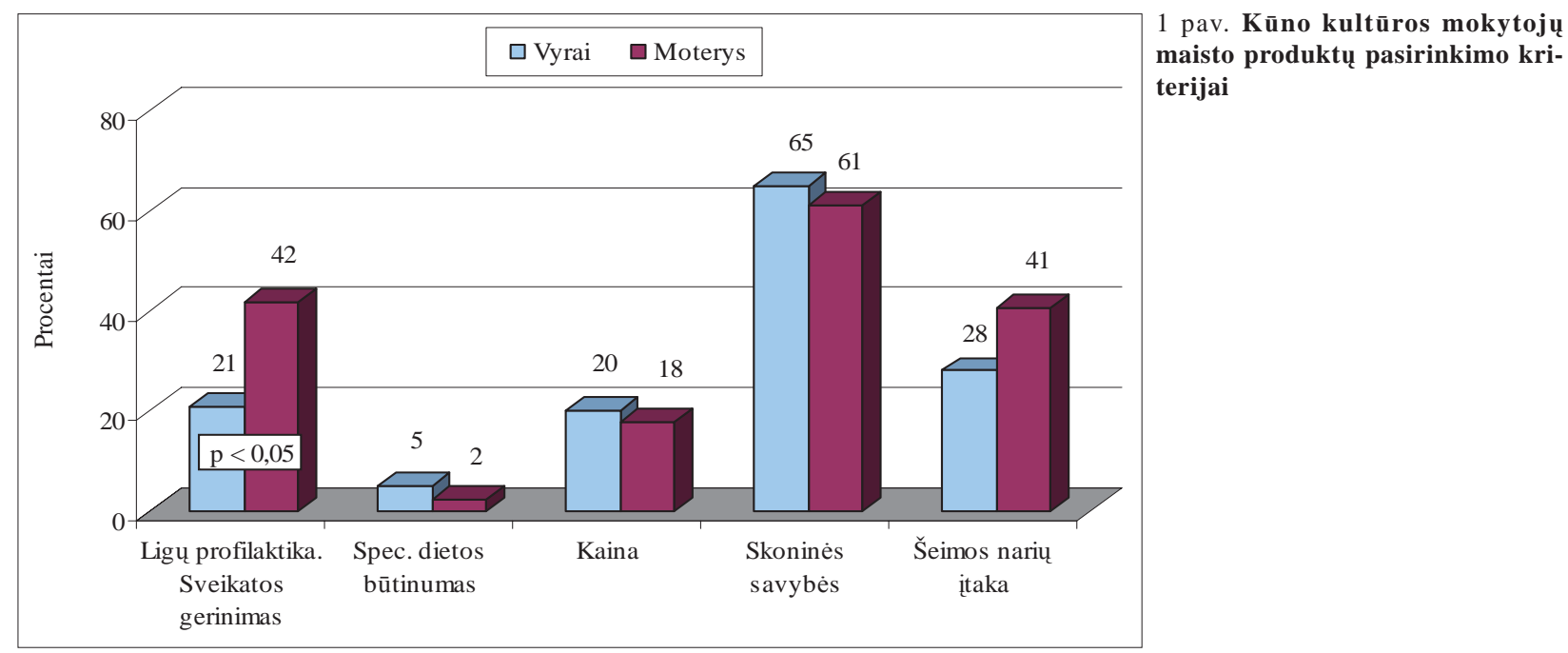


2 pav. Šviežių daržovių vartojimas (kartais per savaitę)

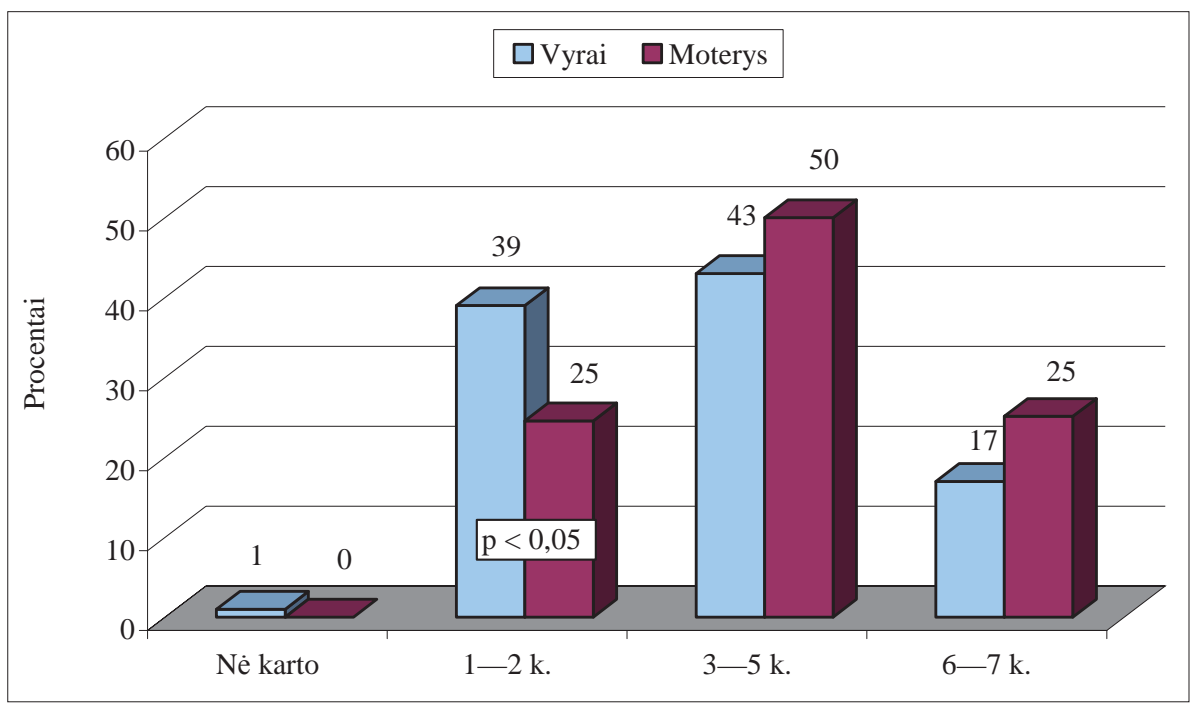

3 pav. Virtų daržovių vartojimas (kartais per savaitę)

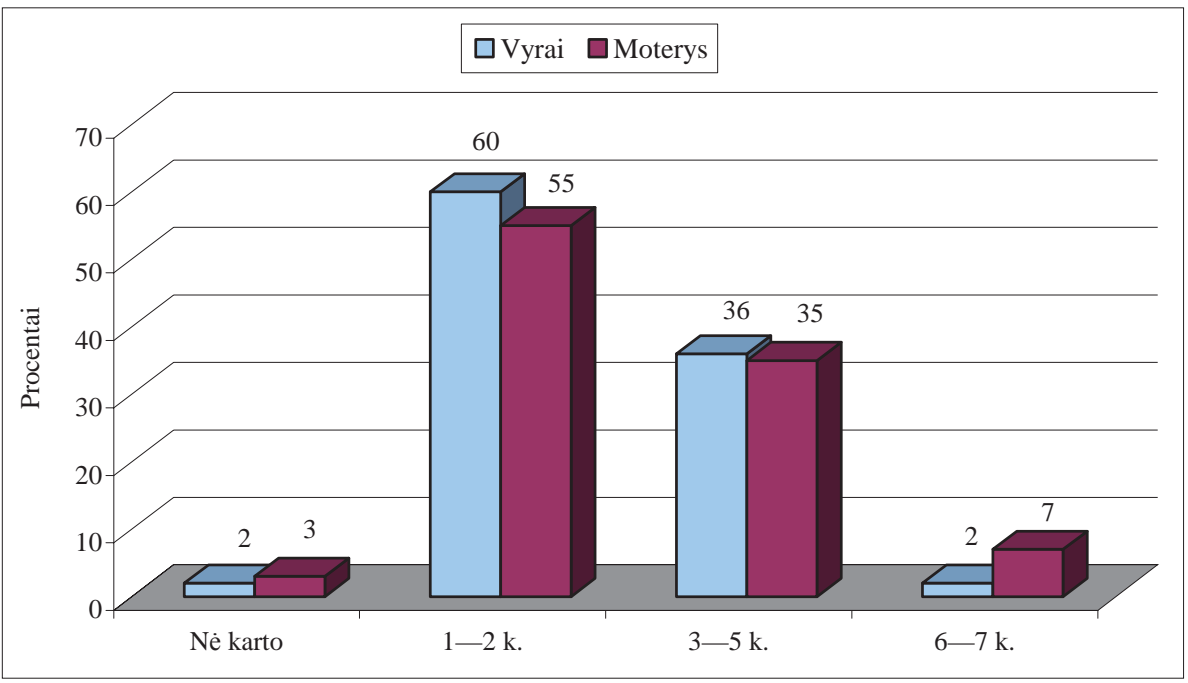

4 pav. Vitaminų ir maisto papildų vartojimas

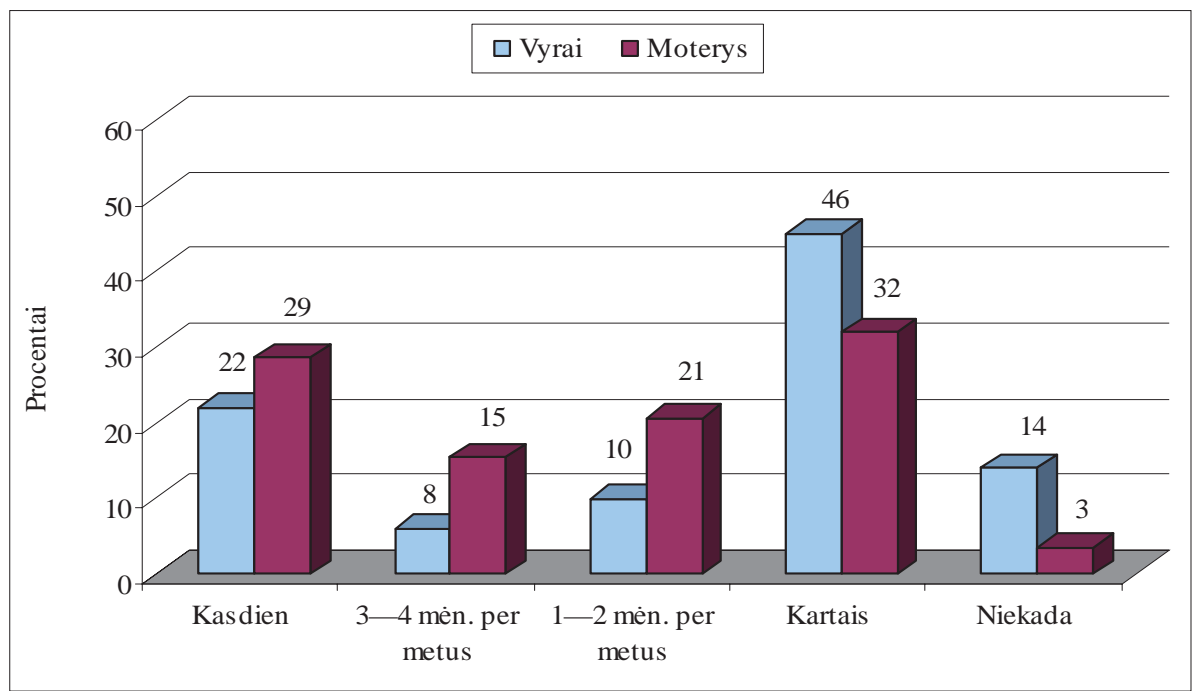

$18 \%$ moteru, pagal specialią dietą $-5 \%$ vyru ir $2 \%$ moterų (1 pav.).

Šviežias daržoves kasdien vartoja 17\% kūno kultūros mokytojų vyrų ir 25\% moterų. Statistiškai patikimai daugiau vyru (39\%) nei moteru (25\%) šviežias daržoves valgo $1-2$ kartus per savaitę.
3-5 kartus per savaitę šviežias daržoves vartoja daugiau moteru (50\%), nei vyru (43\%). Niekada nevartoja šviežių daržovių 1\% tirtų kūno kultūros mokytojų vyrų. Didžioji dauguma tirtu kūno kultūros mokytojų šviežias daržoves valgo $2-5$ kartus per savaitę (2 pav.). 

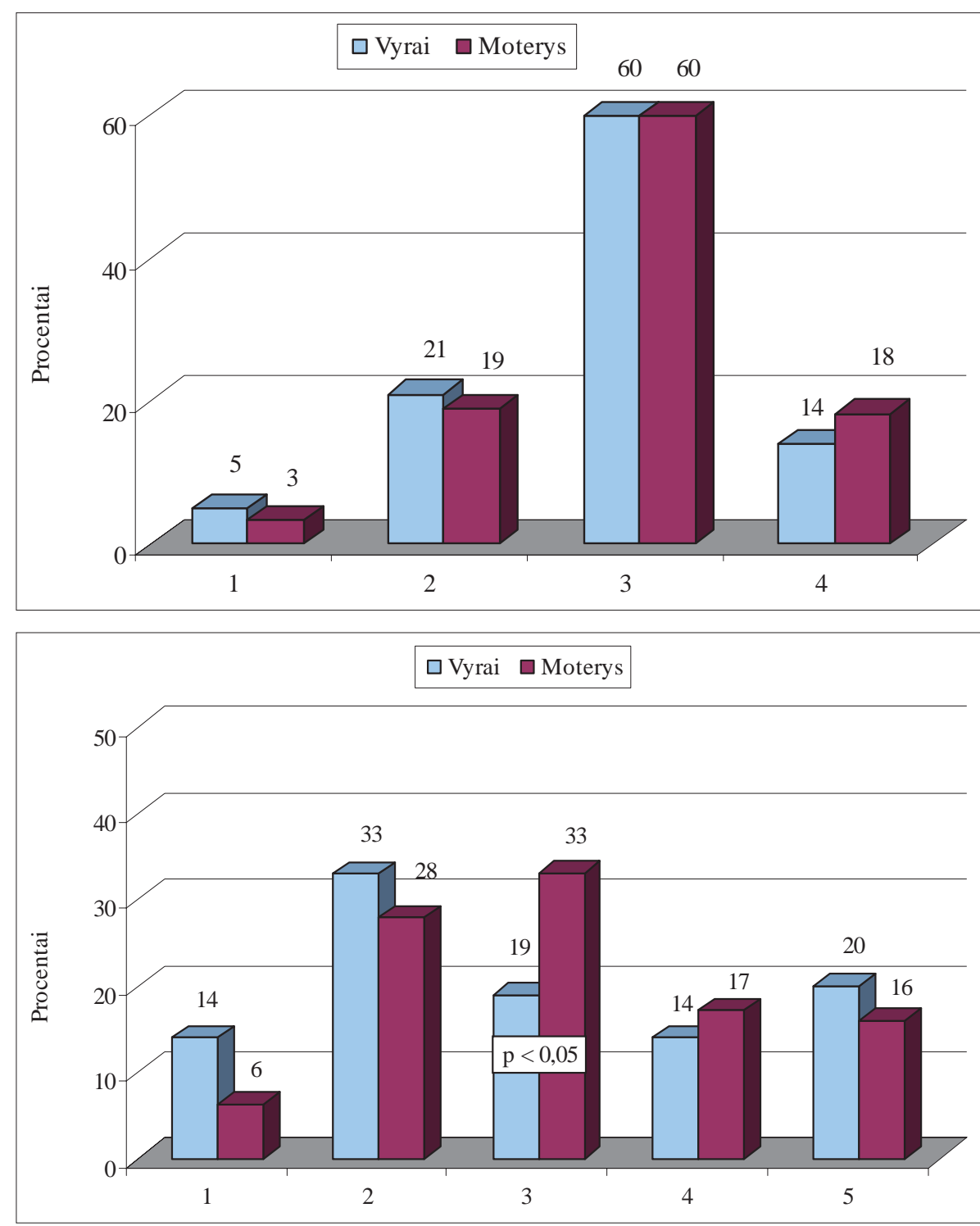

Pastaba.

1. Sunkios treniruotės ir varžybos dažniau nei 1 kartą per savaitę.

2. Lètas bėgimas, kitos fizinio aktyvumo rūšys ar sunkus darbas sode ne mažiau kaip 4 valandas per savaitę.

3. Pasivaikščiojimas, važinejjimasis dviračiu.

4. Kiti lengvi fiziniai pratimai mažiausiai 4 valandas per savaite.

5. Skaitymas, televizoriaus žiūrèjimas ir kiti sėdimo poilsio būdai.

Virtas daržoves kasdien vartoja $2 \%$ kūno kultūros mokytojų vyrų ir 7\% moterų. Virtas daržoves kūno kultūros mokytojai dažniausiai valgo $1-2$ kartus per savaitę (60\% vyrų ir 55\% moteru). 3-5 kartus per savaitę virtas daržoves vartoja $36 \%$ vyrų ir 35\% moteru (3 pav.).

Kasdien vitaminus ir maisto papildus vartoja $22 \%$ vyru ir $29 \%$ moterų. $3-4$ ménesius per metus vitaminus ir maisto papildus vartoja $8 \%$ vyrų ir $15 \%$ moterų. $1-2$ mėnesius per metus vitaminus ir maisto papildus vartoja $10 \%$ vyru ir $21 \%$ moterų. Kartais vitaminus ir maisto papildus vartoja $46 \%$ vyru ir $32 \%$ moterų. Niekada nevartoja vitaminų ir maisto papildų $14 \%$ vyru ir 3\% moterų (4 pav.). 47\% tirtų kūno kultūros mokytojų vyrų ir 54\% moterų vartoja mineralizuotą druską. Pagamintą maistą sūdo $61 \%$ visų tirtų kūno kultūros mokytojų.

Gèrimui ir maistui gaminti kūno kultūros mokytojai vyrai vartoja daugiau virinto (38\%) ir nevirinto šulinio vandens (14\%), o moterys daugiau filtruoto (26\%) ir fasuoto buteliais (39\%). Maistui gaminti 91\% kūno kultūros mokytoju vyrų ir 99\% moterų vartoja augalinį aliejų.

Tirtų kūno kultūros mokytojų vyrų (41\%) statistiškai patikimai daugiau nei moterų (23\%) valgo tuo pačiu metu. Dauguma tirtų kūno kultūros mokytojų turi iprotị užkandžiauti tarp pagrindinių valgymų. Tik 9\% vyrų ir 5\% moterų šio ipročio neturi. Moterys (14\%) dažniau nei vyrai (10\%) užkandžiauja tarp pagrindinių valgymų.

Kūno kultūros mokytojų buvo paprašyta patiems įvertinti savo tiesiogini darbą. Didžioji dauguma kūno kultūros mokytojų savo tiesiogini darbą priskyrè prie vidutinio sunkumo (60\% moteru ir $60 \%$ vyru), $14 \%$ vyru ir $18 \%$ moteru mano esant sunku, o $26 \%$ vyru ir $22 \%$ moteru teigia, kad jis yra lengvas, prilygstantis sėdimam ir stovimam darbui (5 pav.). Kūno kultūros mokytojai praleidžia laisvalaiki fiziškai 
aktyviai. 14\% vyrų laisvalaikiu daug treniruojasi, dalyvauja varžybose daugiau nei kartą per savaitę, $33 \%$ vyrų laisvalaikiu bėgioja ar sunkiai dirba ne mažiau kaip 4 valandas per savaitę. 33\% kūno kultūros mokytojų moterų laisvalaikiu mėgsta pasivaikščioti, važinètis dviračiu. $20 \%$ vyru ir $16 \%$ moterų laisvalaikị leidžia pasyviai skaitydami ar žiūrèdami televizorių (6 pav.). 85\% tirtų kūno kultūros mokytojų vyrų ir 75\% moterų nors kartą per savaitę mankštinasi taip, kad suprakaituotų.

Kūno kultūros mokytojai buvo sveriami, matuojamas jų ūgis. Pagal gautus duomenis buvo apskaičiuotas KMI (kūno masės indeksas). 62\% vyrų ir 50\% moteru kūno masès indeksas atitinka normą (norma vyrams $-20-25 \mathrm{~kg} / \mathrm{m}^{2}$, moterims - 19-24 kg / m² (Lašienè ir Lašas, 1998)). $43 \%$ moteru ir $12 \%$ vyrų kūno masès indeksas per mažas $\left(\mathrm{KMI}<20 \mathrm{~kg} / \mathrm{m}^{2}\right)$. Antsvori turi $7 \%$ tirtų kūno kultūros mokytojų moterų ir $22 \%$ vyrų (KMI - 25,130 kg / $\left.\mathrm{m}^{2}\right) .4 \%$ kūno kultūros mokytojų vyrų yra nutukę (KMI $\left.30,1-40 \mathrm{~kg} / \mathrm{m}^{2}\right)$.

\section{REZULTATŲ APTARIMAS}

Kūno kultūros mokytojų mityba buvo tiriama remiantis sveikos mitybos rekomendacijomis. Tyrimo duomenimis, pagrindinis tirtų kūno kultūros mokytojų maisto produktų pasirinkimo kriterijus - skoninès savybės. Lyginant kūno kultūros mokytojų maisto produktų pasirinkimo kriterijus su Lietuvos gyventoju apklausos rezultatais, pastebèta skirtumų. Lietuvos gyventojų maisto produktu pagrindinis pasirinkimo kriterijus - kaina (68,8\% visų apklaustuju). Ligų profilaktika svarbi pasirenkant maisto produktus tik 8,3\% Lietuvos gyventojų (Kadziauskienè ir kt., 1999).

Suvartojamų daržovių kiekis ir vartojimo dažnumas - svarbi profilaktikos priemone norint išvengti daugelio lètinių neinfekciniu ligų. Kūno kultūros mokytojos dažniau valgo šviežias daržoves nei vyrai. 2004 metų Lietuvos gyventojų apklausos duomenimis, 14,9\% vyrų ir $18,7 \%$ moterų kasdien vartojo šviežias daržoves (Nacionaliness sveikatos tarybos metinis pranešimas, 2004). Kasdien šviežias daržoves valgè $15,8 \%$ aukštaji išsilavinimą turinčių vyru ir 22,1\% moteru (Grabauskas ir kt., 2004 a). Lyginant šių tyrimų rezultatus galima teigti, kad kūno kultūros mokytojai dažniau nei kiti suaugę Lietuvos gyventojai ir asmenys, turintys aukštaji išsilavinima, vartoja šviežias daržoves. Tyrimais nustatyta, kad žmogaus organizmas maistines medžiagas geriau pasisavina iš termiškai apdorotų daržovių ir vaisių. Mūsų tyrimo duomenimis, virtas daržoves $1-2$ kartus per savaitę valgo $60 \%$ tirtų vyrų ir 55\% moterų (3 pav.). Kitų tyrimu duomenys rodo, kad Lietuvos gyventojai virtas daržoves dažniausiai vartoja $1-2$ kartus per savaitę - 46,3\% (Kadziauskienè ir kt., 1999).

Tarp kūno kultūros mokytojų moterys dažniau nei vyrai vartojo vitaminus ir maisto papildus. Populiariausi tarp moterų vitaminai ir maisto papildai: vitaminai C, E, A, mikroelementai Ca, Mg, Se, vitaminų bei mikroelementų kompleksai. Vyrai dažniausiai vartoja vitaminą C ir B grupès vitaminus, mikroelementus Ca ir Mg. Lietuvos gyventojai niekada nevartoja vitaminų bei maisto papildų: 69,5\% vyrų ir 47,2\% moteru (Kadziauskienè ir kt., 1999). Lyginant šių tyrimų rezultatus pastebèta, kad kūno kultūros mokytojai vitaminus ir maisto papildus vartojo dažniau nei vidutinis Lietuvos gyventojas.

Pusẻ visų tirtų kūno kultūros mokytojų vartoja mineralizuotą druską. Kiti tyrimai rodo, kad Lietuvoje tik 4,7\% gyventojų vartoja druską su mineralais ir 8,2\% nežino, kokią druską vartoja (Kadziauskienè ir kt., 1999). Valgomosios druskos perteklius yra vienas iš rizikos veiksnių, galinčių padidinti kraujospūdį. Pagamintą maistą sūdo apie 60\% visų tirtų kūno kultūros mokytojų. 1999 metų Lietuvos gyventojų apklausos duomenimis, pagamintą maistą sūdè apie 53\% gyventojų (Kadziauskienè ir kt., 1999).

Pastaruoju metu atliekama daug geriamojo vandens kokybės tyrimų, kuriais nustatoma, kad ne visada jo kokybė atitinka higienos normas. Šulinių vandenyje randama nitratų, bakterijų, vandentiekio vandenyje - chloro, geležies ir kitu sveikatai žalingu cheminiu elementų (Nacionalinès sveikatos tarybos metinis pranešimas, 2004). Tyrimais nustatyta (Kadziauskiené ir kt., 1999), kad 39\% vyrų ir 35\% moterų vartoja gèrimui netinkamą vandeni, ir tai sudaro prielaidas kai kuriems lètiniams infekciniams ir neinfekciniams susirgimams atsirasti. Vyrai vartojo daugiau virinto vandens, o moterys daugiau filtruoto ir fasuoto buteliais. Net 61,1\% Lietuvos gyventojų gèrimui vartojo nevirinta šulinio ir centralizuoto vandentiekio vandeni (Kadziauskienè ir kt., 1999).

Vienas iš labiausiai kraujotakos sistemos ligas skatinančių veiksniu — riebalai, ypač gyvuliniai, savo sudètyje turintys daug sočiujų riebalų 
rūgščių. Riebalai, i̇ kurių sudètị ieina daugiau polinesočiujų riebalų rūgščių, mažina kraujotakos sistemos ligu atsiradimo riziką (Kadziauskienė ir kt., 1999). Tokiems riebalams priskiriamas aliejus. Maistui gaminti kūno kultūros mokytojai vartojo daugiausia augalini alieju - 91\% vyrų ir 99\% moterų. Lietuvos gyventojai maistui gaminti vartoja îvairius riebalus, o aliejų tuo tikslu vartoja $82,6 \%$ vyrų ir 89,4\% moteru (Lietuvos sveikatos statistika, 2004).

Mitybos režimo labiau laikosi tirti kūno kultūros mokytojai vyrai. Lietuvos gyventoju apklausos duomenimis, 23,2\% gyventoju turi iproti valgyti tuo pačiu laiku (Kadziauskienè ir kt., 1999). Beveik visi mūsų tirti kūno kultūros mokytojai užkandžiauja tarp pagrindinių valgymų. Kiti tyrimai rodo (Kadziauskienè ir kt., 1999), kad 10,5\% tirtų Lietuvos gyventojų niekada neužkandžiauja tarp pagrindinių valgymu.

Mažas fizinis aktyvumas darbo ir poilsio metu yra vienas iš rizikos veiksniu nutukimui atsirasti. Tirtų kūno kultūros mokytojų vyrų fizinis aktyvumas laisvalaikiu didesnis nei moteru. 85\% tirtų kūno kultūros mokytojų vyrų ir 75\% moterų mankštinasi bent kartą per savaitę taip, kad suprakaituotuc. Kitų tyrimų duomenimis, 2002 m. laisvalaikiu mankštinosi vidutiniškai $48,2 \%$ suaugusiu Lietuvos vyrų ir $42,1 \%$ moteru (Grabauskas, 2004 b). 2004 m. Lietuvoje laisva- laikiu mankštinosi 30,3\% vyru ir 28,7\% moteru (Lietuvos sveikatos statistika, 2004). Lyginant tyrimų duomenis matyti, kad kūno kultūros mokytojai laisvalaikiu beveik dvigubai aktyvesni negu suaugę Lietuvos gyventojai.

Apskaičiavus kūno kultūros mokytojų kūno masės indeksą nustatyta, kad antsvorį turi tik 22\% vyrų ir 7\% moterų. Nutukimo požymių aptikta tik tarp $4 \%$ vyrų. Tačiau net $43 \%$ moterų ir $12 \%$ vyru svoris yra per mažas.

\section{IŠVADOS}

1. Tirti kūno kultūros mokytojai maitinasi ne visada pagal sveikos mitybos reikalavimus. Šviežias daržoves moterys vartoja dažniau nei vyrai. Pagamintą maistą papildomai sūdo 60\% respondentų. Dauguma tirtų kūno kultūros mokytojų maistui gaminti vartoja augalinį aliejų (91\% vyrų ir 99\% moteru), bet nesilaiko mitybos režimo, užkandžiauja tarp pagrindinių valgymų.

2. Kūno kultūros mokytojai yra pakankamai fiziškai aktyvūs ir tiesioginiame darbe, ir laisvalaikiu. Didesnè dalis (60\%) tirtų kūno kultūros mokytojų savo tiesiogini darbą vertina kaip vidutinio sunkumo. 85\% kūno kultūros mokytojų vyrų ir $75 \%$ moterų bent kartą per savaitę mankštinasi.

\section{LITERATŪRA}

Almonaitienė, J., Antinienė, D., Ausmanienė, N. ir kt. (2001). Bendravimo psichologija: vadovèlis. Kaunas: Technologija.

Baranovski, T. (2004). Why rombine diet and physical activity in the same international research society? International Journal of Behavioral Nutrition and Physical Activity, 1, 2.

Grabauskas, V., Petkevičienė, J., Kriaučionienė, V., Klumbienè, J. (2004 a). Lietuvos gyventojų sveikatos skirtumai: išsimokslinimas ir mitybos ipročiai. Medicina, 9 (40), 875-882.

Grabauskas, V., Zaborskis, A., Klumbienè, J., Petkevičienè, J., Žemaitienè, N. (2004 b). Lietuvos paaugliu ir suaugusių žmonių gyvensenos pokyčiai 1994-2002 metais. Medicina, 9 (40), 884-890.

Kadziauskienè, K., Bartkevičiūtė, R., Olechnovič, M. ir kt. (1999). Suaugusiu Lietuvos žmoniu gyvensenos ir faktiškos mitybos tyrimas 1997-1998. Vilnius: Respublikinis mitybos centras.

Lašienė, D., Lašas, L. (1998). Nutukimas ir jo gydymas. Kaunas: Naujasis Lankas.
Lepeškienè, V. (1996). Humanistinis ugdymas mokykloje. Vilnius: Valstybinis leidybos centras.

Lietuvos bendrojo lavinimo mokyklos bendrosios programos ir bendrojo išsilavinimo standartai. (2002). Prieiga per internetą: http://www.pedagogika.lt/bps.htm

Lietuvos sveikatos statistika. (2004). Prieiga per internetą: http://www.lsic.lt/

Nacionalinès sveikatos tarybos metinis pranešimas. (2004). Lietuvos sveikatos programos igyvendinimas: pasiekimai ir problemos. Vilnius: Baltijos kopija.

Puišienè, E., Ciegienè, R. (2005). Kaimo pradinių klasių moksleivių sveikatos ir jų ugdytojų sveikatos nuostatos sąsajos. Ugdymas. Kūno kultūra. Sportas, 1 (55), 34-43.

Sveikatos apsaugos ministerijos Respublikinis mitybos centras. (1998). Prieiga per internetą: http://www.vsv. lt/gyvensena/

Weare, K., Gray, G. (1995). Protinès ir emocinès sveikatos stiprinimas Europos sveikatos mokyklu tinkle: mokymo priemone. Vilnius: Informacijos ir leidybos centras. 


\title{
THE STUDY OF PE TEACHERS NUTRITION AND PHYSICAL ACTIVITY FROM THE WELLNESS PERSPECTIVE
}

\author{
Daiva Vizbaraitė, Vida Česnaitienè \\ Lithuanian Academy of Physical Education, Kaunas, Lithuania
}

\begin{abstract}
The general programs at Lithuanian secondary schools and educational standards emphasize the importance of the knowledge about healthy living while promoting successful development of physical education. The activity of physical education (PE) teacher is closely related to health education and PE teacher's personal competence has a very large educational impact on it. Thus we have a problematic question to answer and would like to know if PE teachers themselves lead healthy living while promoting healthy lifestyle.

The aim of this research is to investigate PE teachers' nutrition and physical activity. All the investigated consisted of 320 PE teachers (184 men and 136 women) who had been selected randomly from all PE teachers at Lithuanian secondary schools. The average age of all the investigated is $42.5 \pm 21.5$. With the help of the questionnaire the PE teachers' nutrition and physical activity have been investigated. The questionnaire of Real Nutrition and Healthy Living of Lithuanian people was used referring to the questionnaire of the Nutrition Centre of our Republic and World Health Organization by 1997-1998 obtained data (Kadziauskiene et al., 1999). The results of the research have been expressed in per cent and the data of the research is statistically significant, if the bias is $\mathrm{p}<0.05$ the statistical link is evaluated by chi criteria $\left(\chi^{2}\right)$.

The research showed that PE teachers don't use enough fresh and boiled vegetables. Women eat more fresh vegetables than men. The main product in the nutrition of all investigated PE teachers are their gustatory properties. PE women teachers use vitamins or food supplements more often than men. It was noticed that all the investigated overdose salt. Half of all the investigated have been using mineralised salt. $39 \%$ of men and $35 \%$ of women use wrong water. Nearly all investigated PE teachers were using seed-oil to prepare their food. Most of them didn't keep to proper nutrition as they were having snacks between main meals. $22 \%$ of all investigated PE teachers' men and 7\% women had overweight.

PE teachers are physically active. $60 \%$ of PE teachers attributed their job to a rather hard one. $85 \%$ of men and $75 \%$ of women do exercises in their free time. Men are more physically active in their leisure time than women.
\end{abstract}

Keywords: physical education, nutrition, physical activity.

Daiva Vizbaraite

Lietuvos kūno kultūros akademija

(Lithuanian Academy of Physical Education)

Sporto g. 6, LT-44221 Kaunas

Lietuva (Lithuania)

Tel +37037302671

E-mail d.vizbaraite@lkka.lt 